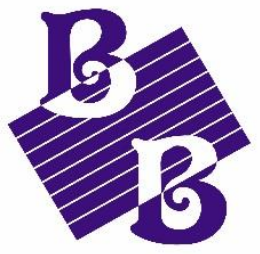

BioBacta

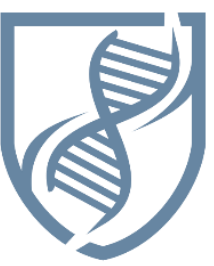

Journal of Bioscience and Applied Research

www.jbaar.org

\title{
Effectiveness of Back Strengthening Exercise on Pain and Disability among the Nursing Students with Mechanical Low Back Pain
}

\author{
Jinu K Rajan \\ Department of Nursing, College of Applied Medical Sciences \\ Majmaah University, Kingdom of Saudi Arabia \\ Email:jinukrajan@rediffmail.com \\ DOI: 10.21608/jbaar.2018.155994
}

\begin{abstract}
Introduction: Health is a fundamental right. Every human being has the right to enjoy the highest attainable standard of health. According to WHO, health is a state of complete physical mental, social and spiritual wellbeing, not merely an absence of disease or infirmity (Potter PA, Perry AG, 2010). The musculoskeletal system is particularly vulnerable to external forces. These forces can cause alteration in the structure of bone or soft connective tissue, resulting in functional disruption. The consequences may be deformity, alteration of body image, mobility, pain, or permanent disability. These problems may produce long-term health problems that interfere with activities of daily living and quality of life (Lewis SM, Heitkemper MM, Dirksen SR, 2007).

Materials and Methods: A pre-experimental study was carried out to assess the effectiveness of back strengthening exercise on pain and disability among nursing students with mechanical low back pain in Index Nursing College, Indore.

The objectives of the study were to assess the intensity of low back pain and disability before and after the back strengthening exercises, assess the effectiveness of back strengthening exercise on low back pain, disability and associate the level of low back pain with selected demographic variables. One group pre-test post-test design was used and a purposive sampling technique was applied.

Results: Samples were selected using case detection proforma. 60 students who met the inclusion criteria were recruited for the back strengthening exercise intervention. The intervention was carried out daily for 30 minutes for 30 days. The severity of low back pain and disability before and after the intervention were assessed using the Numerical pain rating scale and Modified Oswestry Low Back Pain Disability Questionnaire respectively. The analysis revealed that the post-test pain and disability score was significantly less than the pre-test pain and disability score.

Conclusion: Thus back strengthening exercise was found to be effective in reducing low back pain and disability among the nursing students. There was no significant association between the pre-test pain score and the selected demographic variables like age, height, weight, course of study, year of study, activities aggravating low back pain.
\end{abstract}

Keywords: effectiveness; back strengthening exercises; mechanical low back pain; disability; nursing students 


\section{INTRODUCTION}

Low back pain is a universal experience among adults and the prevalence of disabling back pain has increased greatly during the past 20 years. This increase has been attributing to society's expectations of management for back pain (Lewis SM, Heitkemper MM, Dirksen SR, 2007 ).

Musculoskeletal disorders (MSD) constitute a major proportion of all registered and/or compensable work-related diseases in many countries, representing a third or more of all registered occupational diseases. The physical ergonomic features of work that are most frequently cited as musculoskeletal disorder risk factors include rapid work pace and repetitive motion patterns, insufficient recovery time, heavy lifting and other forceful manual exertions, non-neutral body postures (either dynamic or static), mechanical pressure concentrations, vibration (both segmental and whole-body), and low temperature (Punnett. L, 2005).

Low back pain is extremely common worldwide. Almost every person will have at least one episode of low back pain at some time in his or her life. The pain can vary from mild to severe and from shortterm to long-term. It resolves within a few weeks for most people (Hoy O, Brooks P, Blyth F, Buchbinder $\mathrm{R}, 2010$ ).

\section{MATERIALS AND METHODS}

To accomplish the objectives of the study a quantitative approach was used for the study. In the present study, the researcher used a one-group pretest post-test design which is a pre-experimental design. One group pre-test post-test design is the simplest type of pre-experimental design, where only the experimental group is selected as the study subjects. In the present study, the independent variable is the back strengthening exercises ( McKenzie's extension exercises) and the dependent variables are the mechanical low back pain and disability among the nursing students.

The study was conducted at Index Nursing College, Indore, which has both General nursing, midwifery, and basic BSc nursing courses which was mainly the target population. The sample consists of 60 nursing students from BSc and general nursing students with mechanical low back pain.
From a total population of 194 nursing students excluding the first years, samples were identified with a case detection Proforma which contains questions to rule out and exclude non-mechanical low back pain cases. A sample of 60 students who meet the criteria was selected. The data collection instruments used were case detection Proforma, demographic Proforma, Numerical pain rating scale, and Modified Oswestry Low Back Pain Disability Index.

\section{RESULTS}

\section{Section 1: Distribution of the subjects according to demographic variables.}

The demographic variables of the subjects are described in terms of age, height, weight, religion, course of study, year of study, family history of low back pain, activities aggravating low back pain. 


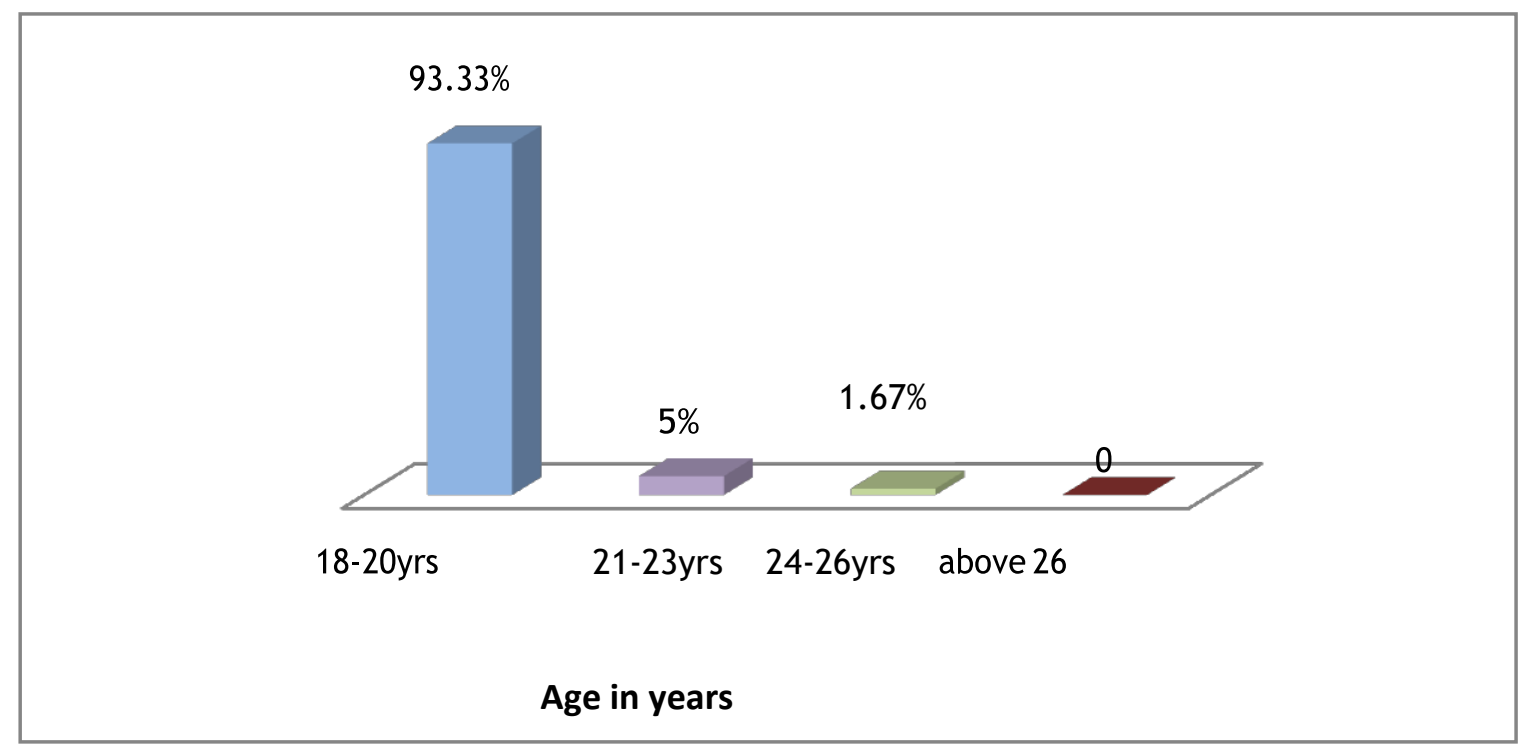

Fig 3.1: Percentage distribution of subjects according to their age

Figure 3.1 shows that the maximum number of subjects 56 (93.33\%) belongs to the age group of 18-20 yrs and $3(5 \%)$ belongs to age group 21-23yrs. 1 (1.67\%) belongs to age group 24-26 yrs. There are no students above the age of 26 .

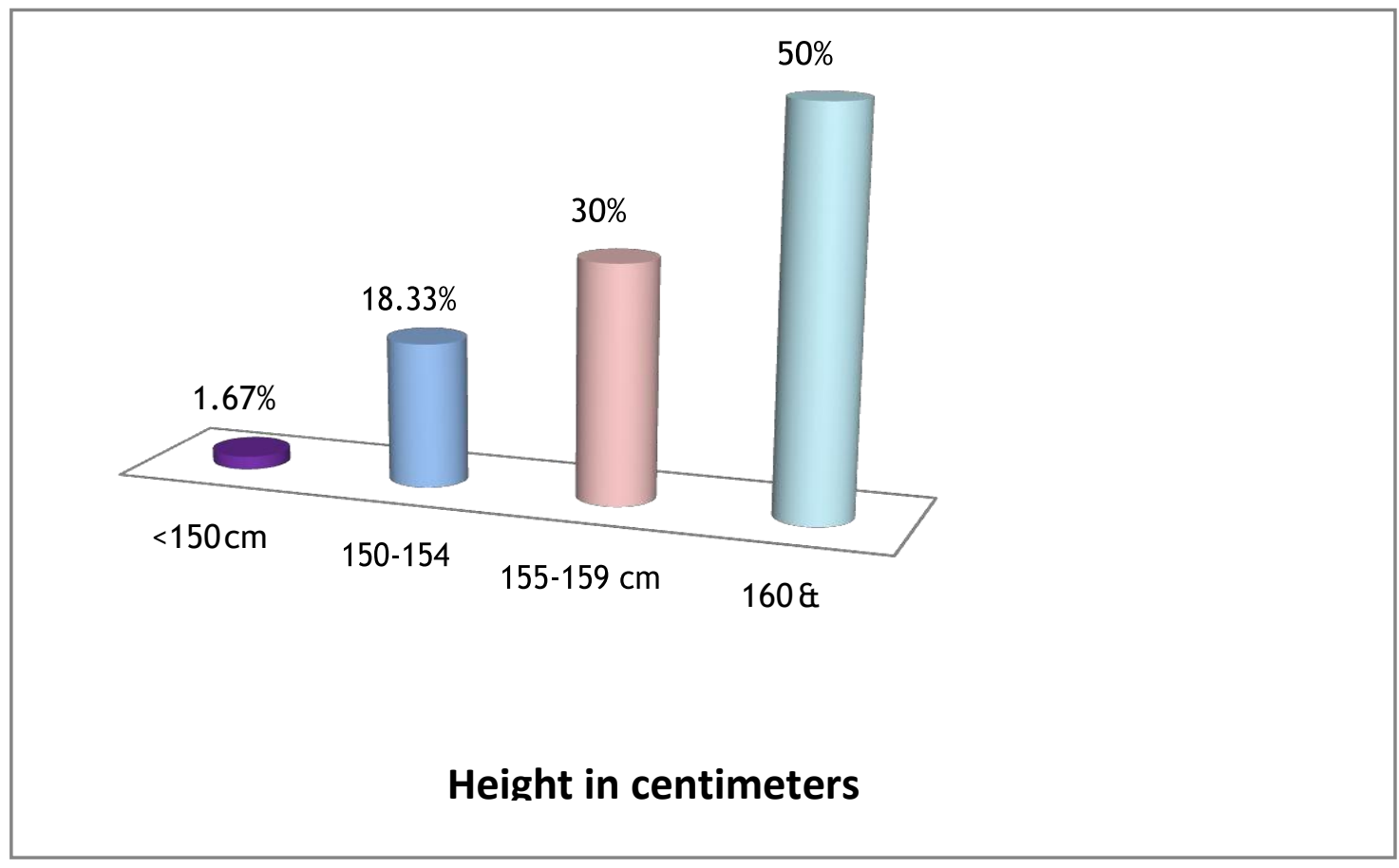

Fig 3.2: Percentage distribution of students according to their height

Fig 3.2 shows that the Majority of the students $30(50 \%)$ had a height of $160 \mathrm{~cm}$ and above. 18 students (30\%) had $155-159 \mathrm{~cm}$ height and 11 students (18.33\%) had 150-154 cm height. Only 1student $(1.67 \%)$ had $<150 \mathrm{~cm}$ height. 


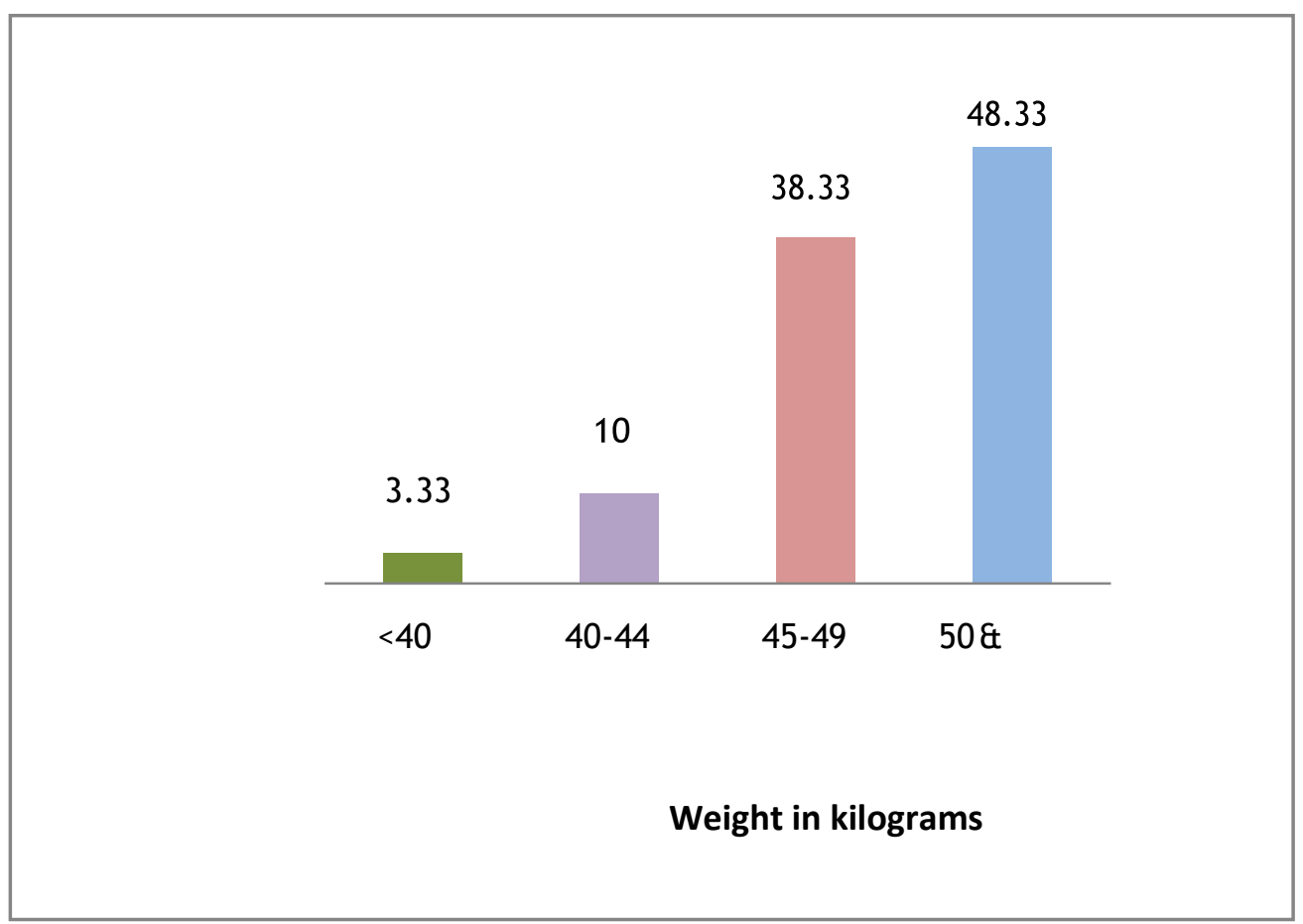

Fig 3.3: percentage distribution of students according to their weight

Fig 3.3 Implies that the maximum number of students 29 (48.33\%) had $50 \mathrm{Kg}$ and above weight. 23 students (38.33\%) had 45-49 Kg weight and 6 students (10\%) had 40-44 Kg Weight and only 2 students $(3.33 \%)$ had $<40 \mathrm{Kg}$ weight.

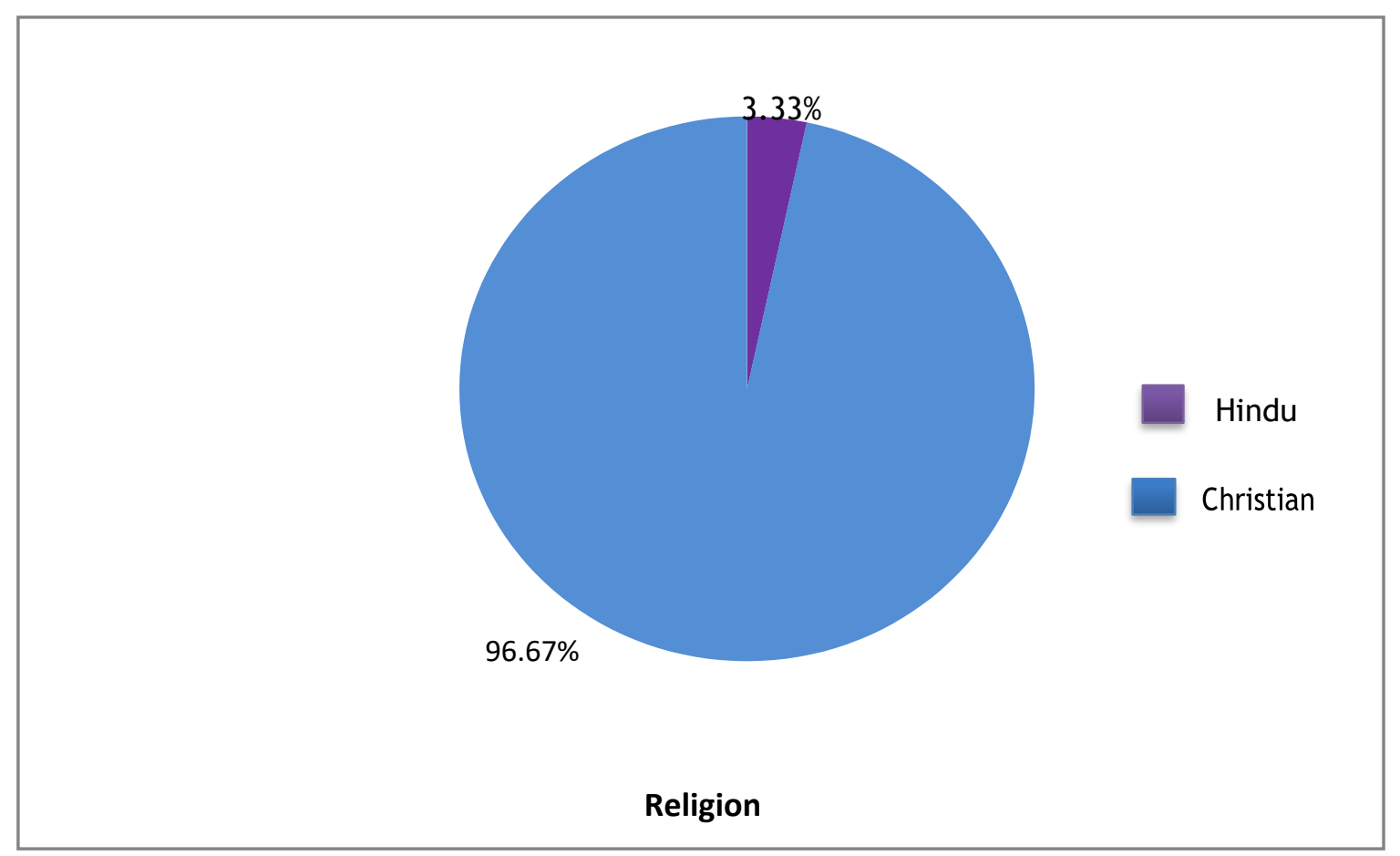

Figure 3.4: Percentage distribution of subjects according to religion

Figure 3.4 shows that the majority $96.67 \%$ of the students were Christians and $3.33 \%$ of the students were Hindus. 


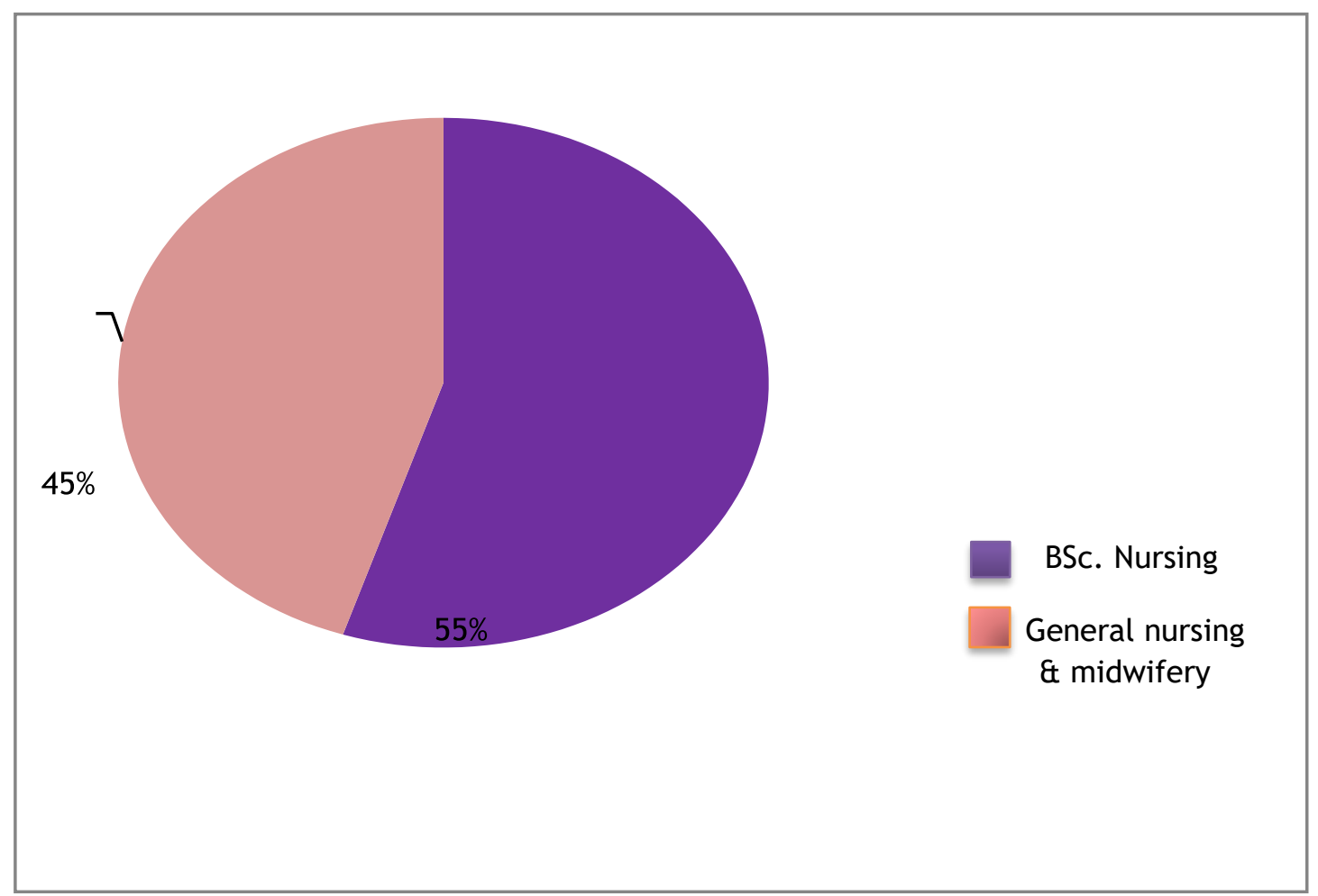

Fig 3.5: percentage distribution of students according to course of study

Figure 3.5 shows that $55 \%$ of the students belonged to BSc.Nursing and $45 \%$ of the students belonged to General Nursing and Midwifery course.

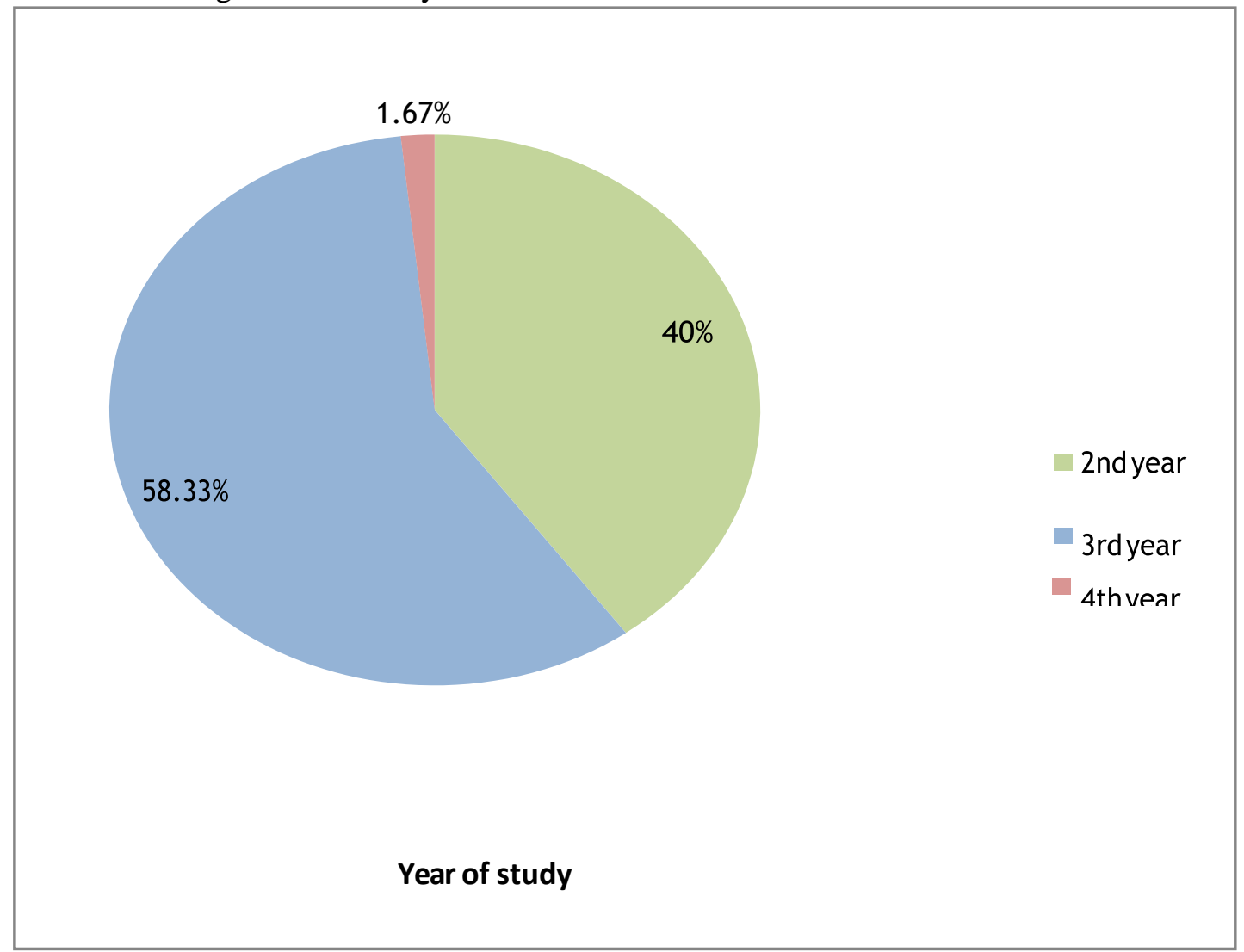

Figure 3.6: Percentage distribution of students according to their year of study

Figure 3.6 shows that $58.3 \%$ of the students belong to the $3^{\text {rd }}$ year nursing, $40 \%$ of the students belonging to the $2^{\text {nd }}$ year, and $1.67 \%$ of the students belonging to the $4^{\text {th }}$ year. 


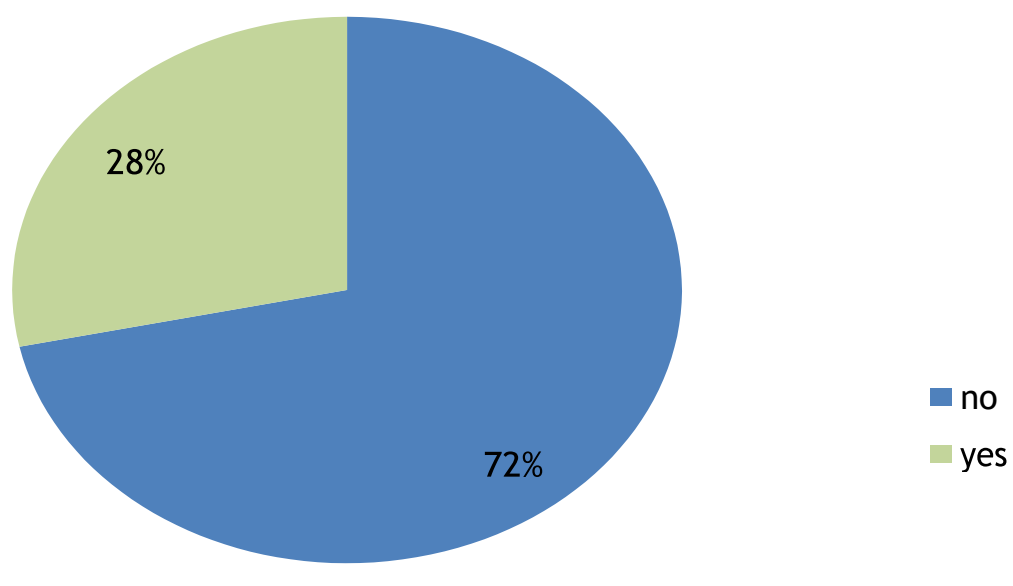

Family history of low back pain

Figure 3.7: Percentage distribution of samples according to a family history of low back pain

Figure 3.7 shows that $72 \%$ of the students had no family history of low back pain and $28 \%$ of the students reported a family history of low back pain.

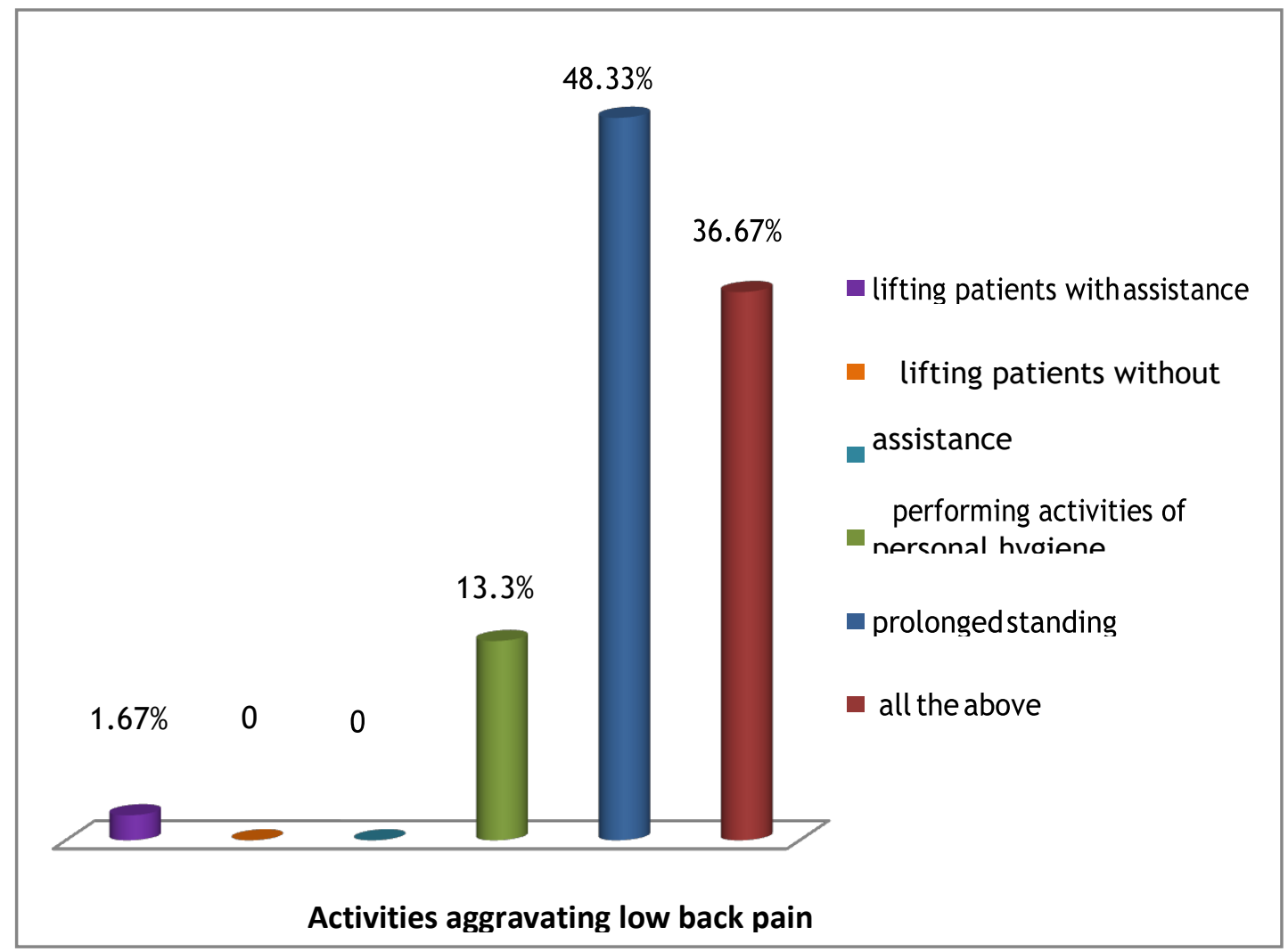

Figure 3.8: Percentage distribution of the students according to the activities aggravating the low back pain

Figure 3.8 shows that the majority of the students $(48.33 \%)$ reported that prolonged standing is the activity that aggravates low back pain. $1.67 \%$ of the students reported lifting patients with assistance is the activity that aggravates low back pain and $13.3 \%$ of the students reported bending during procedures aggravates the low back pain. $36.67 \%$ of the students reported that all the above activities aggravate low back pain. 
Section II: Distribution of subjects with referent to pre-test and post-test score.

This section deals with the percentage distribution of samples according to their pre-test and post-test scores on pain and disability.

Table 1: Frequency and percentage distribution of sample according to pre-test pain score $(\mathbf{n}=60)$

\begin{tabular}{lcl} 
Intensity of pain & frequency (F) & perce \\
\cline { 2 - 3 } & & \\
No pain & 0 & 0 \\
Mild pain & 10 & 16.7 \\
Moderate pain & 42 & 70 \\
Severe pain & 8 & 13.3
\end{tabular}

Data presented in table 1 show that $70 \%$ of the samples had a moderate intensity of low back pain, $16.7 \%$ had a mild intensity of low back pain, $13.3 \%$ had a severe intensity of low back pain and none of the samples reported any low back pain during the pre-test assessment of pain.

Table 2: Frequency and percentage distribution of the sample according to pre-test level of disability $(\mathbf{n}=60)$

Level of disability frequency (F) Percentage (\%)

0\%-20\% mild

$20 \%-40 \%$ moderate

$40 \%-60 \%$ severe

$60 \%-80 \%$ crippled
24

30

6

0
40

50

10

0

Data presented in the Table 2 shows that $50 \%$ of the students had moderate disability, $40 \%$ had a mild disability and $10 \%$ had a severe disability during the pre-test assessment on the level of disability 
Table 3: Frequency and percentage distribution of the samples according to post-test pain score $(\mathrm{n}=60)$

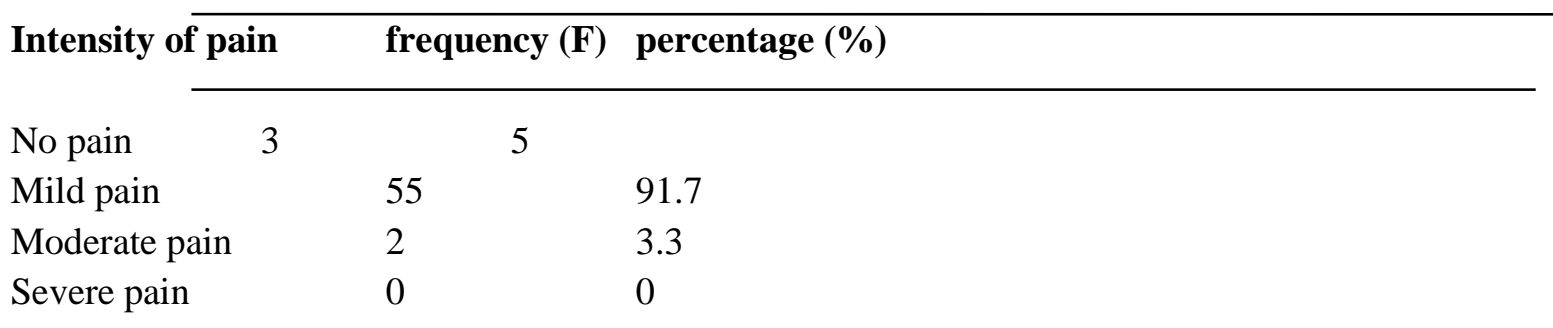

Data presented in table 3 shows that $91.7 \%$ of the students had mild pain, $5 \%$ had no pain and $3.3 \%$ had moderate pain. No one had severe pain after the back strengthening exercises.

Table 4: Frequency and percentage distribution of the samples according to a post-test level of disability $(\mathrm{n}=60)$

\section{Level of disability $\quad$ frequency (F) Percentage (\%)}

$0 \%-20 \%$ mild $\quad 50 \quad 83.3$

$20 \%-40 \%$ moderate $\quad 10 \quad 16.7$

$40 \%-60 \%$ severe $\quad 0 \quad 0$

60\%-80\% crippled $0 \quad 0$

Data presented in Table 4 shows that $83.3 \%$ of students had a mild level of disability and $16.7 \%$ had a moderate level of disability after the back strengthening exercises. 


\section{Section III: Effectiveness of back strengthening} exercise on low back pain and disability

For studying the effectiveness of back strengthening exercises on low back pain and disability, the scores related to the intensity of pain and level of disability were assessed before and after the administration of back strengthening exercises. Paired_t $t^{6}$ test was used to find out the statistical significance of the difference in scores between pre-test and post-test. Reduction in the intensity of pain and level of disability as evidenced by a significant difference in scores indicates the effectiveness of back strengthening exercises.

\section{Comparison between pre-test and post-test pain scores}

$\mathrm{H}_{1:}$ the post-test pain score after the back strengthening exercises will be significantly lower than the pre-test pain score in nursing students.

Table 5: Comparison between pre-test and post-test pain scores

$(\mathrm{n}=60)$

\begin{tabular}{|c|c|c|c|c|}
\hline & & & Paired & „P'e \\
\hline Pain score & Mean & $\begin{array}{l}\text { Standard } \\
\text { Deviation }\end{array}$ & ,t'te value & value \\
\hline
\end{tabular}

Pre-test

4.95

$1.17 \quad 0.000$

Post-test $\quad 1.93$

** Highly significant at 0.001 level table value, $\mathrm{t}_{(59)}=3.46$

Data presented in table 5 shows that the mean pre-test pain score was 4.95 and that the post-test pain score was 1.93 . There was a significant difference in the mean scores before and after the administration of back strengthening exercises. The calculated $t$ value is greater than the table. $t$ value at $p=0.001$. Thus the research hypothesis $\mathrm{H}_{1}$ was accepted. 


\section{Comparison of pre-test and post-test level of disability}

$\mathrm{H}_{2:}$ The post-test disability score after back strengthening exercise will be significantly lower than the pre-test disability score in nursing students.

Table 6: Comparison between pre-test and post-test level of disability

$(\mathbf{n}=60)$

\begin{tabular}{lcccc}
\hline Level of Disability & Mean & $\begin{array}{l}\text { Standard } \\
\text { deviation }\end{array}$ & Paired & "Pee \\
& & & Value \\
& & & \\
Pretest & 0.24 & 0.084 & $12.91^{* * *}$ & 0.000 \\
& & & \\
Post-test & 0.10 & & &
\end{tabular}

**Highly significant at 0.001 level

The data presented in table 6 shows that the mean post-test disability $(0.10)$ was less than the mean pre-test disability (0.24). The calculated $t$ value is greater than the table. $t$ value at $p=0.001$. Hence the research hypothesis $\mathrm{H}_{2}$ is accepted.

\section{Section 4: Association of pre-test pain score with selected demographic variables.}

The selected demographic variables like age, height, weight, course of study, year of study, and activities aggravating low back pain of the nursing students were associated with the pre-test pain scores. A Chisquare test was used to find the association.

To test the association between the pre-test pain scores and selected demographic variables, the following null hypothesis was stated and tested using chi-square.

$\mathrm{H}_{02}$ : there will be no significant association between the pre-test pain score and the selected demographic variables such as age, height, weight, course of study, year of study, and activities aggravating low back pain. 
Table 7: Association between Pre -Test pain score and selected demographic variables

$(\mathrm{n}=60)$

\begin{tabular}{|c|c|c|c|c|c|}
\hline & Sl. No: demographic & variables & $X^{2}$ value & Df & level of significance \\
\hline 1. & Age & 0.32 & 1 & & $\mathrm{p}>0.05$ \\
\hline 2 & Height & 0.004 & 1 & & $\mathrm{p}>0.05$ \\
\hline 3. & Weight & 0.84 & 1 & & $\mathrm{p}>0.05$ \\
\hline 4 & Course of study & 2.00 & 1 & & $\mathrm{p}>0.05$ \\
\hline 5. & Year of study & 0.14 & 2 & & $\mathrm{p}>0.05$ \\
\hline 6. & Activities aggravating & 2.80 & 3 & & $\mathrm{p}>0.05$ \\
\hline
\end{tabular}

Table value: $X^{2}{ }_{(1)}=3.84, X_{(2)}^{2}=5.99, X^{2}{ }_{(3)}=7.82$

The data presented in table 7 shows that there is no significant association between the demographic variable and low back pain. So the research hypothesis is rejected and $\mathrm{H}_{02}$ is accepted.

\section{DISCUSSION}

Assess the intensity of low back pain before and after the back strengthening exercises

In this group, most $(70 \%)$ of the samples had moderate pain whereas $13.3 \%$ samples had severe pain and the remaining $16.7 \%$ had mild pain.

Assess the level of disability before and after the back strengthening exercises

In this group majority (50\%) of the samples had a moderate level of disability, whereas $40 \%$ of the samples had a mild level of disability and $10 \%$ of the samples had a severe level of disability before the back strengthening exercises. After the back strengthening exercises, the majority $(91.7 \%)$ of the samples had mild pain and $3.3 \%$ of the samples had moderate pain and 5\% had no pain. The findings of this study are consistent with other studies with Bureau of Labour Statistics, 2002, Nelson A, Fragla G, Menzel Nancy, 2003, Smith DR, Sato M, Miyajima T,2003.
Assess the effectiveness of back strengthening exercise on pain and disability

This study revealed that the mean pre-test (4.95) pain score was greater than the mean post-test (1.93) pain score. The statistical test reveals that the reduction of low back pain is highly significant $\mathrm{t}=19.94(\mathrm{p}=0.00)$ which is less than 0.01 level of significance. The findings of this study are consistent with other studies with June KJ \& Cho SH,2010, Nair RR \& D'silva,2011, Moffett JK, Torgerson D \& Bell-Syer S et. al,1999.

\section{Conclusion}

The present study aimed to find the effectiveness of back strengthening exercises on pain and disability among nursing students with mechanical low back pain. The study results show that there was a significant $(\mathrm{p}=0.00<0.01)$ reduction in pain among nursing students after the back strengthening exercises. It also shows a significant difference in mean pre-test and post-test pain scores. So the back 
strengthening exercises were effective in reducing the pain among nursing students with mechanical low back pain. The mean pre-test (0.24) disability score was greater than the mean post-test $(0.10)$ disability score and $\mathrm{p}=0.00$, which is less than 0.01 level of significance.

\section{REFERENCES}

1. Alexopoulos EC, Burdorf A, Kalokerinou A. A comparative analysis on musculoskeletal disorders between Greek and Dutch nursing personnel. Int Arch Occup Environ Health. 2006 Jan; 79 (1): 82-8. Available from http://www.ncbi.nlm.nih.gov/pubmed/16 133523

2. Anap DB, Iyer C, Rao K. Work-related musculoskeletal disorders among hospital nurses in rural Maharastra, India: A multicenter survey. Int J Res Med Sci. 2013, 1 (2): 101-107 Available from www.scopemed.org/?mno=35915.

3. Back care for nurses: study available from:

URL:

http://www.spineuniverse.com/displayar ticle,php/article1509.html.

4. Barrientos MC, Nelson DI, Driscoll T, et al. Selected occupational risk factors.Available from URL: http:// www. who. int/ publications /cra/chapters/ volume2/1651-1802.pdf

5. Basavanthappa BT. Nursing research. $2^{\text {nd }}$ edition. New Delhi: Jaypee Brothers; 2007

6. Berman A, Synder SJ, Kozier B, Erb G. Fundamentals of Nursing Concept, Process and Practice. $8^{\text {th }}$ edition. India: Dorling Kinersley; 2008.

7. Black JM, Hawks JH, Keene AM. Medical-surgical nursing. $6^{\text {th }}$ edition.Philadelphia: Elsevier Mosby;2006.

8. Bos E, Krol B, van der Star L, Groothoff J. Risk factors and musculoskeletal complaints in non-specialized nurses, IC nurses, operation room nurses, and X-ray technologists. Int Arch Occup Environ
Health. 2007 Jan; 80 (3): 198-206. Available from http://www.ncbi.nlm.nih.gov/pubmed/16 799823

9. Bureau of Labour Statistics 2002. Survey of occupational injuries and illness.2001. Department of labor. USDL 2002 Dec 19.

10. Burns N, Grove SK. Understanding Nursing Research, building an evidencebased practice. $4^{\text {th }}$ edition. St. Louis: Saunders; 2008.

11. Carneiro Machado L A, von Sperling de Souza M, Ferreira PH, Ferreira M L. The McKenzie method for low back pain: a systematic review of the literature with a meta-analysis approach. Spine 2006; 31(9): E254-E262. Available from http://www.ncbi.nlm.nih.gov/pubmedhe alth/PMH0023226/

12. Chung YC, Chin T, Li S. Risk of musculoskeletal disorders among Taiwanese Nurses Cohort: A Nationwide population-based study. BMC Musculoskeletal Disorders. 2013, 14: 144. Available from ) http :// www. biomedcentral. com/1471-2474/14/144

13. Chung YC, hung CT, Li SF, Lee HM, BMC Musculoskeletal Disord. 2013 April 23;14:144.doi.10.1186/1471-247414-144. Available from URL:http://www. ncbi.nlm.nib.gov/pubmed/23617330

14. Clare HA, Adams R, Maher CG. A systematic review of efficacy of McKenzie therapy for spinal pain. Aust J Physiother. 2004; 50 (4): 209-16. Available from http://www.ncbi.nlm.nih.gov/pubmed/15 574109

15. Connie GS. Watch your back nursing personnel can prevent workplace injuries before they happen. National Association of orthopedic nurses journal 2001 Jan 8

16. Cooper's spine. 1996 oct 15;21 (20): 2329-2336. Available at http://gateway.ut.Ovid.Com/gwl/ovidwe b.cgi 
17. Eriksen W. The prevalence of musculoskeletal pain in Norwegian nurses' aides.

18. Fritz JM, Irrqanq JJ. A comparison of modified Oswestry Low Back Pain Disability Questionnaire and the Quebec Back Pain Disability Scale. Phys.

19. Garcia AN, Costa LM. Effectiveness OF Back School Versus McKenzie Exercises in Patients with Chronic Nonspecific Low Back Pain: A Randomized Controlled Trial. Physical Therapy. 2013, June vol. 93 (6): 729-47. Available from: http://ptjournal.apta.org/content/93/6/72 9.abstract

20. Hongo M, Itoi E, Sinaki M, Miyakoshi N, Shimada Y, Maekawa S, et al.Effect of low-intensity back exercise on quality of life and back extensor strength in patients with osteoporosis: a randomized controlled trial. Osteoporos Int. 2007 Oct; 18 (10): 1389-95. Available from http: //www. ncbi. nlm. nih.gov /Pubmed/17572835

21. Hoy O, Brooks P, Blyth F, Buchbinder R. The epidemiology of low back pain.Best practice and research clinical rheumatology 24(2010)769-781

22. International archives of occupational and environmental health. 2003 Oct; vol.76 (8): 625-30. Available from URL: http: //link. springer. com/article/10.1007/ s00420-003-04536.

23. Is back pain spreading like epidemic. Indian Times. 2010 April 15. Available from articles. The Times of India. indiantimes.com/2010-04-15/ Kanpur/ 28132422_1_ pain-posture-sedentary lifestyle.

24. Jensen RC. Disabling back injuries among nursing personal: research needs and justification

25. June KJ, Cho SH. Low back pain and work-related factors among nurses in Intensive Care Units. Journal of Clinical Nursing. 2010. Vol 20: 479-87. Available from http: //www. jpp. perawatpintar. web.id/index. $\quad \mathrm{php} / \mathrm{jpp} /$ article/viewFile/18/pdf

26. Karahan A, Bayraktar N. Determination of the usage of body mechanics in clinical settings and occurrence of low back pain in nurses. Int J Nurs Stud. 2004 Jan; 41 (1): 67-75. Available from ncbi. nlm. nih. gov/ pubmwww.ed/ 14670396

27. Karahan A., Kav S., Abbasoglu A. \& Dogan N. Low back pain: prevalence and associated risk factors among hospital staff. Journal of Advanced Nursing (2009) 65(3), 516-524.

28. Kim DH, Albert TJ, Hilibrand AS, Vaccaro AR. Epidemiology, pathophysiology, and clinical evaluation of low back pain. American academy of orthopedic surgeons. October 2005; (2):11-18.

29. Kofotolis N, Kellis E. Effect of 4-week proprioceptive neuromuscular facilitation programs on muscle endurance, flexibility, and functional performance in women with chronic low back pain. Phys Ther, 2006 Jul; 86 (7): 1001-12. Available from: http://www.ncbi.nlm.nih.gov/pubmed/16 813479

30. Koley S, Sharma L, Kaur S. Effects of Occupational Exposure to Whole -Body Vibration in Tractor Driver with Low Back Pain in Punjab. Anthropologist, 2010, 12 (3): 183-87. Available from http://www.krepublishers.com

31. Kumar S, Negi MPS, Sharma VP, Shukla R, Dev R, Mishra UK. Effectiveness of back strengthening exercises in reducing low back pain. Journal of Back and Musculoskeletal Rehabilitation 2009;22(3):179-88.

32. Lewis SM, Heitkemper MM, Dirksen SR. Medical-Surgical Nursing. $9^{\mathrm{h}}$ edition. St.Louis: Elsevier Mosby; 2007.

33. Lorusso A, Bruno S, Labbate A. A review of low back pain and musculoskeletal disorders among Italian nursing personnel. Industrial Health. 2007; 45, 637-44. 
34. Mandy Mitchle More. Back to life: Nursing Times 1996 June 5; 92(23):17.

35. Manek NJ, Mac Gregor AJ. Epidemiology of back disorders: prevalence, risk factors, and prognosis. Curr Opin Rheumatol. 2005; 17:134-40

36. Marriner TA, Raile AM. Nursing theorists and their work. In: Sakraida T.

Nola J Pender. The Health Promotion Model. St. Louis: Mosby;2005.

37. Maul I, Laubli T, Klipstein A, Krueger H. Course of low back pain among nurses: a longitudinal study across eight years. Occup Environ Med 2003; 60: 497-503. Available from http: // www. ncbi. nlm. nih. gov/pmc/ articles/ PMC1740571/pdf/v060p00497.pdf

38. Mitchelle T, O'Sullivan PB, Burnett AF. Low back pain characteristics from undergraduate student to working nurse in Australia: A cross-sectional survey. Int J Nurs Stud.2008 Nov; 45 (11): 1636-44. Available from http://www.ncbi.nlm.nih.gov/pubmed/18 420208

39. Moffett JK, Torgerson D, Bell-Syer S, Jackson D, Llewlyn-Phillips H, Farrin A, Barber J. Randomised controlled trial of exercise for low back pain: clinical outcomes, costs, and preferences. BMJ 1999 Jul 31; 319 (7205): 279-83. Available from: http://www.ncbi.nlm.nih.gov/pubmed/10 426734

40. Mohseni-Bandpei MA, Fakhri M, Bagheri-Nesami M, Ahmad-Shirvani M, Khalilian AR, Shayesteh-Azar M. Occupational back pain in Iranian nurses: an epidemiological study. Br J Nurs 2006 Sep 28; 15 (17): 914-17.Available from http://www.ncbi.nlm.nih.gov/pubmed/17 077782

41. Mustafa AF, Fiala LA. Prevalence and risk factors of low back pain among nurses in four tertiary care hospitals at King Fahad Medical City, Riyadh, KSA. Med J Cairo Univ. 2010 June Vol 78 (2): 219-23. Available from http://medicaljournalofcairouniversity.ne t/index/images/pdf/2010/june/51.pdf

42. Nair RR, D'silva. Effectiveness of back strengthening exercises on low back pain among nursing students. Indian Journal of Continuing Nursing Education. 2011, $12(2): 27-33$

43. Nelson A, Fragla G, Menzel Nancy. Myths and facts about back injuries in nursing. An J Nur 2003 Feb; 103 (2): 32 40.

44. Norris C, Matthews M. The role of an integrated back stability program in patients with chronic low back pain. Complementary therapies in Clinical Practice. 2008; 14,n 25563.Available from http: //medicine. tums.ac.ir:803/Users/reza_mazaheri/Jour nal\%20club/Journal\%2088-05-12/

45. Nourbakhsh MR, Arab AM. Relationship between mechanical factors and incidence of low back pain. J Orthop Sports Phys Ther. 2002 Sep; 32 (9): 447Available from http://www.ncbi.nlm.nih.gov/pubmed/12 322811

46. Pareek B, Sharma S. A textbook of nursing research and statistics. $3^{\text {rd }}$ edition. India. PV Books; 2001.

47. Petersen T, Kryger P, Ekdahl C, Olsen S, Jacobsen S. The effect of McKenzie therapy as compared with that of intensive strengthening training for the treatment of patients with subacute or chronic low back pain: A randomized controlled trial. Spine (Phila Pa 1976). 2002 Aug 15;27 (16): 1702-9. Available from

http://www.ncbi.nlm.nih.gov/pubmed/12 195058

48. Polit DF, Beck CT. Nursing Research, Generating and Assessing Evidence for Nursing Practice. $9^{\text {th }}$ edition. New Delhi: Wolters Kluwer; 2012.

49. Potter PA, Perry AG. Basic Nursing. $9^{\text {th }}$ edition. St.Louis: Elsevier Mosby; 2010.

50. Punnett. L. Estimating the global burden of low back pain attribute to combined 
occupational exposure. American journal of industrial medicine. June 2005; 48:459-469. Available from www. who. int/ quantifying_ ehimpacts/global/ 5lowbackpain.pdf.

51. Rao KR. Prevalence of knowledge of low back pain among students of selected nursing Institutions. International Journal of Nursing Education. 2011, 3 (1): 82. Available from http://connection.ebscohost.com/c/article s/78174230/

52. Sara. Ten more reasons every day. Nursing times. 1996 Dec 4; 92 (49): 49

53. Sharma SK. Nursing research and statistics. India. Elsevier;2011.

54. Sikiru L, Shmaila H. Prevalence and risk factors of low back pain among nurses in Africa: Nigerian and Ethiopian specialized hospitals survey study. East Afr J Public Health. 2009 April; 6 (1): 22 5. Available from http://www.ncbi.nlm.nih.gov/pubmed/20 000059

55. Singh A, Sonia DY, John S. Epidemiology of musculoskeletal pain in Indian nursing students. International Journal of Nursing Education. 2010. Vol 2 (2):.6-8. Available from http: //www. Indian journals. com/ijor.aspx? target =ijor: ijone \&type=home

56. Smith D R. Leggat PA. Musculoskeletal disorders among rural Australian nursing students. Australian Journal of rural health Dec 2004; 12(6): 241-245

57. Smith DR, Mihashi M, Adachi Y, Koqa $\mathrm{H}$, Ishitake T. A Detailed analysis of musculoskeletal disorder risk factors among Japanese nurses. JSafety Res. 2006; 37 (2): 195-200. Available from URL http: //www. ncbi. nlm. nih. gov/ Pubmed/16678854.

58. Smith DR, Sato M, Miyajima T. Musculoskeletal disorders self-reported by female nursing students in Central Japan: A complete cross-sectional Survey. International Journal of Nursing Studies.2003 Sep. Vol 40 (7): 725-29. Available from http://www.ncbi.nlm.nih.gov/pubmed/12 965164

59. Sopajareeya C, Viwatwongkasem C. Prevalence and risk factors of low back pain among nurses in a Thai Public Hospital. J Med Assoc Thai 2009; 92 (suppl 7): S93-9. Available from http: //bios.ph. Mahidol.ac. the/muphbsweb/ staff/publication/Chukiat/Chukiat_pub_2 009_4.pdf

60. Tate RB, Yassi A, Cooper J. Predictors of time loss after back injury in nurses.Spine. 1999; 24 (18): 1930-5.

61. Ther. 2001 Feb; 81 (2): 776-88. Available from http:// www.ncbi. nlm.nih. gov/ pubmed/11175676

62. Vieira ER, Kumar S, Coury HJ, Narayan Y. Low back problems and possible improvements in nursing jobs. J Adv Nurs. 2006 July; 55 (1) 79-89. Available from http://www.ncbi.nlm.nih.gov/pubmed/16 768742

63. Willis F. Moving and handling: Guidelines for back care. Nursing times 1996 Dec 4; 92 (49): 48

64. Wong TS, Teo N, Kyaw,MO. Prevalence and risk factors associated with low back pain among health care providers in a District hospital. Malaysian Orthopaedic Journal 2010. Vol 4 (2) 23-28. Available from

http://www.morthoj.org/2010v4n2/Low_ Back_Pain.pdf

65. Wong TS. Prevalence and risk factors associated with low back pain among health care providers in a district hospital. Malaysian orthopedic journal. 2010. Vol. $4 ; 23-24$. 